\title{
Perancangan dan Implementasi Security System pada Sepeda Motor Menggunakan RFID Sensor Berbasis Raspberry Pi
}

\author{
Haris Isyanto ${ }^{1}$, Akhmad Solikhin ${ }^{2}$, Wahyu Ibrahim ${ }^{3}$ \\ ${ }^{1,2,3)}$ Jurusan Teknik Elektro, Fakultas Teknik Universitas Muhammadiyah Jakarta \\ ${ }^{1,2,3)} \mathrm{Jl}$. Cempaka Putih Tengah 27, Jakarta Pusat 10510 \\ ${ }^{1)}$ haris.isyanto@ftumj.ac.id
}

\begin{abstract}
Abstrak
Di era modern seperti saat ini, sepeda motor sudah menjadi kebutuhan pokok untuk keperluan transportasi bagi hampir semua kalangan. Selain karena harganya yang terjangkau, penggunaan dan perawatannya yang mudah menjadi alasan mengapa banyak orang yang menggunakannya. Tetapi bersamaan dengan itu, tindak kriminal pencurian sepeda motor pun semakin meningkat. Atas latar belakang itulah maka dirancang sebuah alat pengaman tambahan pada penelitian ini. Alat yang dibuat menggunakan 3 (tiga) buah sistem keamanan, yaitu RFID scanner, RF modul communication, dan GPS function. RFID scanner berfungsi sebagai kunci tambahan, di mana selain kartu (tag) yang didaftarkan tidak ada kartu lain yang bisa digunakan untuk menyalakan relay. RF module communication berfungsi agar apabila pengemudi dan sepeda motor terpisah sejauh $n$ meter, maka mesin sepeda motor akan mati secara otomatis. GPS berfungsi untuk memonitor / melacak di mana lokasi sepeda motor berada. Hasil yang didapatkan pada perancangan alat ini adalah RFID scanner dapat men scan kartu pada jarak $0-4 \mathrm{~cm}$ dan pada sudut $0-60^{\circ} \& 120-180^{\circ}$. RF modul dapat berkomunikasi pada jarak 0 - 20 meter tanpa penghalang, dan GPS modul dapat merespon SMS dari pengguna dalam waktu 27 detik dengan tingkat akurasi 10 meter.
\end{abstract}

Kata kunci: Sepeda motor, RFID scanner, RF modul, GPS modul, Relay.

\begin{abstract}
In the modern era like today, motorcycle have become a staple for transportation needs for almost all circles. In addition to the affordable price, easy use and maintenance is the reason why many people use it. But at the same time, criminal acts of motorcycle theft also increased. For this background, an additional safety system was designed in this final project. The system is made using 3 (three) security systems, namely RFID scanner, RF communication module, and GPS function. RFID scanner functions as an additional key, where in addition to the card (tag) registered there is no other card that can be used to turn on the relay. RF module communication functions so that if the driver and motorcycle are separated by $n$ meters, the motorcycle engine will automatically turn off. GPS serves to monitor / track where the motorcycle is located. The results obtained in the design of this system is that the RFID scanner can scan cards at a distance between $0-4 \mathrm{~cm}$ and angle between $0-60^{\circ} \& 120-180^{\circ}$. The RF module can communicate at a distance between $0-20$ meters without a barrier, and the GPS module can respond to SMS from users within 27 seconds with an accuracy of 10 meters.
\end{abstract}

Keywords : Motorcycle, RFID scanner, RF module, GPS module, Relay

\section{PENDAHULUAN}

\subsection{Latar Belakang}

Sepeda motor merupakan ken-daraan yang lazim digunakan oleh semua kalangan; mulai dari kalangan atas, menengah, sampai kalangan bawah. Sayangnya bersamaan dengan itu, tingkat kriminalitas pencurian sepeda motor pun semakin banyak terjadi. Sejauh ini produsen sepeda motor memang sudah menerapkan sistem keamanan tambahan pada sepeda motor buatan mereka seperti adanya ignition key dan shutter key, namun kenyataannya sistem keamanan tersebut masih bisa dengan mudah dibobol oleh oknum spesialis pencurian sepeda motor. Seiring dengan kemajuan teknologi, tantangan bagi produsen sepeda motor untuk menciptakan sistem keamanan yang lebih tinggi pun terus meningkat demi menciptakan rasa aman bagi konsumennya.

Untuk mengatasi masalah ini, maka dirancang sebuah sistem keamanan tambahan pada sepeda motor dengan memanfaatkan modul RFID. RFID atau Radio Frequency Identification merupakan suatu perangkat telekomunikasi data dengan 
menggunakan gelombang radio untuk melakukan pertukaran data antara sebuah reader dengan suatu electronic tag yang ditempelkan pada suatu objek tertentu (Daniel et al., 2007). Selain itu, akan ditambahkan pula modul GPS sehingga user dapat mengetahui posisi dimana sepeda motornya berada. Sepeda motor konvensional hanya menggunakan kunci (kontak) biasa untuk meng-on-kan sistem kelistrikan pada sepeda motor. RFID juga bisa dimanfaatkan untuk keamanan pada rumah[1].

Di sini penulis akan memanfaatkan RFID sensor untuk menambahkan safety system. Dengan digunakannya RFID sensor, maka hanya beberapa RFID TAG saja yang sudah diregister sebelumnya yang bisa digunakan untuk menyalakan sistem kelistrikan sepeda motor tersebut. Dengan kata lain, pencuri sepeda motor tidak akan bisa menyalakan sepeda motor yang telah dipasang alat ini, walaupun kunci kontaknya telah berhasil dibobol.

\subsection{Tujuan Penelitian}

Tujuan penelitian ini adalah sebagai berikut:

1. Membuat sebuah alat ke-amanan tambahan pada sepeda motor dengan memanfaatkan modul RFID, modul RF, dan modul GPS.

2. Mengetahui lokasi dimana sepeda motor berada secara real time via SMS yang dapat terhubung dengan aplikasi Google Map.

3. Mengurangi tindak kriminal pencurian sepeda motor.

\subsection{Rumusan Masalah}

Rumusan masalah pada penelitian ini diantaranya sebagai berikut:

1. Bagaimana cara membuat sistem keamanan tambahan pada sepeda motor meng-gunakan RFID sensor dengan baik dan benar?

2. Bagaimana cara kerja dari alat sistem keamanan pada sepeda motor menggunakan RFID sensor?

3. Bagaimana cara menginte-grasikan RFID sensor, RF modul, GPS modul, LCD display, dan raspberry pi dengan beban berupa relay modul?

\subsection{Batasan Masalah}

Agar penelitian ini terfokus pada permasalahan, maka ruang lingkup penelitian ini dibatasi pada :

1. Menggunakan RFID sensor, RF modul, GPS modul, raspberry pi, dan LCD display sebagai komponen utama.

2. RFID reader yang digunakan adalah tipe pasif USB RFID reader $13.56 \mathrm{MHz}$ merk SYC Reader.

3. RFID tag yang digunakan adalah tipe kartu tag pasif standar dengan frekuensi kerja $13.56 \mathrm{MHz}$.
4. Kartu RFID (RFID Tag) yang diregister adalah sebanyak 2 buah.

5. GPS modul yang digunakan adalah GPS tracker tipe TK110 yang terintegrasi dengan GSM modul.

6. Permintaan lokasi / koordinat dilakukan dengan cara mengi-rim SMS ke nomor SIM card yang dimasukkan ke dalam modul GPS.

7. LCD display yang digunakan adalah tipe $20 \times 04$ standar dengan modul backpack dan komunikasinya dengan rasp-berry pi menggunakan IIC /I2C/I2C.

8. Menggunakan sepeda motor Suzuki Satria Fu 150 CC tipe karburator sebagai implemen-tasi alat yang dibuat.

9. Mikrokontroler yang diguna-kan adalah Raspberry Pi board tipe 3 model B versi 1.2 made in UK dengan OS Raspbian dan bahasa pemrograman Python 3.

\section{TINJAUAN PUSTAKA}

\subsection{Radio Frequency Identification (RFID)}

Radio Frequency Identification (RFID) adalah sistem yang mentransmisikan identitas tertentu berupa nomor unik dari suatu objek menggunakan gelombang frekuensi radio. Teknologi ini termasuk bagian dari teknologi identifikasi otomatis seperti barcode, optical character reader, dan beberapa teknologi biometric seperti retinal scan. RF Modul (modul frekuensi radio) adalah perangkat elektronik yang digunakan untuk mengirim atau menerima sinyal radio antara dua perangkat [2]. Fitur-fitur yang dimiliki oleh teknologi RFID ini menjadi keunggulan dari teknologi RFID jika dibandingkan dengan sistem identifikasi lainnya seperti barcode dan kartu magnetis [3]. RFID (Radio-Frequency Identification) merupakan perangkat elektronik yang kecil, terdiri dari small chip dan sebuah antenna [4]. Kunci pintu dengan RFID pada dasarnya sama dengan kunci pintu yang lain, biasanya tedapat sensor, unit prosesor dan relay magnetic [5].

Salah satu usaha untuk melakukan pengkodean dengan lebar garis dan mengkorepondensikannya dengan suatu data biner tertentu adalah identifikasi dengan barcode. Identifikasi barcode memiliki kekurangan yaitu terbentuk hubungan Line of Sight (LOS) antara barcode tersebut dengan alat pembacanya (reader). Reader barcode bekerja dengan gelombang inframerah. Suatu cara penentuan identitas secara tanpa kontak adalah pengidentifikasi dengan gelombang radio. Sistem operasi yang dapat digunakan pada Raspberry Pi antara lain Raspbian, Pidora, OpenElec, RaspBMC, RISC OS, Arch Linux 
ARM, dan lain-lain [6]. Contoh aplikasi Raspberry Pi adalah control switch otomatis pada tegangan energi alternatif dan tegangan sumber PLN [7].

Gambar 1 menunjukkan sistem RFID dan proses pengidentifikasian suatu objek yang padanya didekatkan sebuah tag (sisi kanan). Tag terdiri dari chip (Integrated Circuit atau IC) yang memiliki perangkat pemancar - penerima (transceiver), memiliki memori yang bisa ditulis dan dihapus. Pada tag pasif bahkan tag tidak memiliki sumber energi.

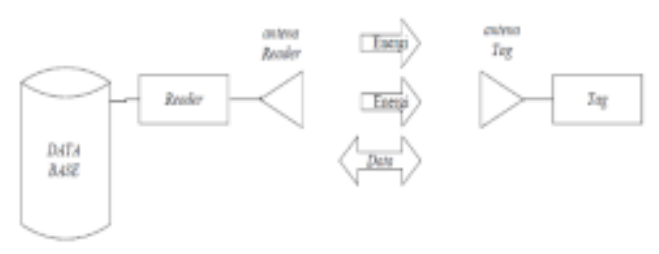

Gambar 1 Bagan sistem RFID [8].

\subsection{RF Modul}

RF (radio frequency) modul adalah perangkat elektronik yang digunakan untuk mengirim atau menerima sinyal radio antara dua perangkat. RF modul yang digunakan adalah RF Modul $433 \mathrm{MHz}$ AK-RXB17-L. Terdapat 2 komponen yaitu transmitter modul dan receiver modul yang menggunakan modulasi ASK. Amplitudo-shift keying (ASK) merupakan bentuk modulasi amplitudo yang mewakili data digital sebagai variasi amplitudo gelombang pembawa.

\subsection{Global Positioning System (GPS)}

GPS tracking adalah suatu sistem pemantauan jarak jauh yang menggunakan Satelit GPS sebagai penentu lokasi kendaraan / asset bergerak dengan tepat dan akurat dalam bentuk titik koordinat. Lokasi dari kendaraan / asset kemudian akan ditampilkan di peta digital yang sangat mudah dimengerti bahkan oleh orang yang tidak pernah melihat peta sekalipun.

Pada saat GPS tracker dipasang di kendaraan, receiver GPS akan segera menerima sinyal koordinat di mana posisi kendaraan berada. Setiap beberapa detik sekali, SIM card yang dipasang dalam GPS tracker akan mengirimkan koordinat posisi kendaraan ke server pelacakan dengan menggunakan jaringan GSM/ GPRS. Data koordinat tersebut kemudian akan dimasukan ke dalam peta digital yang mudah dipahami sehingga dapat menggambarkan rute perjalanan kendaraan sampai dengan lokasi terakhir kendaraan. Peta digital tersebut dapat diakses melalui website tracking yang telah dibuat oleh produsen GPS tracker.

\subsection{PERANCANGAN}

\subsubsection{Gambaran Sistem}

Pada penelitian ini, penulis akan membuat sebuah sistem keamanan tambahan pada sepeda motor dengan memanfaatkan sensor RFID, RF modul, dan GPS modul. Jalur kelistrikan sepeda motor yang menuju ke sistem pengapian (CDI) akan diputus, kemudian disambungkan dengan sebuah relay modul 2 channel. Satu channel digunakan untuk identifikasi RFID tag, dan channel lainnya disambungkan dengan RF receiver modul. Relay channel ini di pasang pada bagian output dari dioda kiprok (tegangan 12 VDC) yang menuju ke CDI sehingga untuk menyalakan kelistrikan sepeda motor tersebut, kunci kontak dan relay modul harus berada dalam kondisi ON.

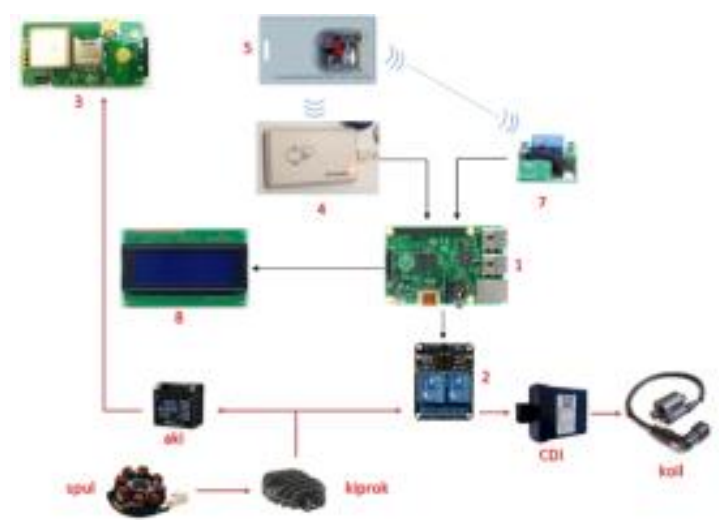

Gambar 2 Blok diagram system.

Keterangan gambar 2:

1. Mikrokontroler raspberry pi

2. Relay modul 2 channel

3. GPS modul

4. RFID reader

5. RFID tag

6. Transmitter modul

7. Receiver modul

8. LCD display 
e-ISSN : 2621-9700, p-ISSN : 2654-2684

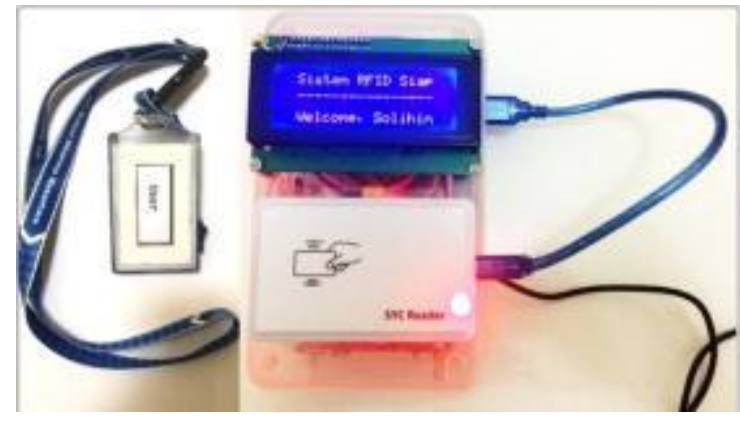

Gambar 3 Sistem tampak depan.

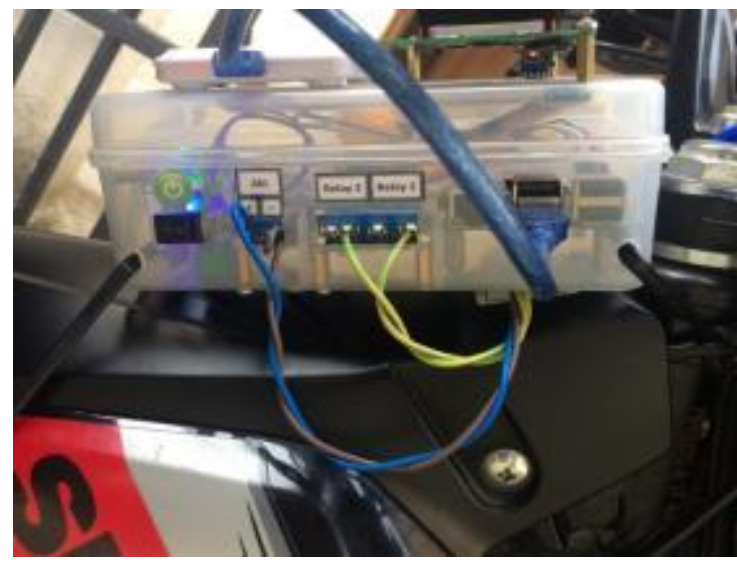

Gambar 4 Sistem tampak samping.

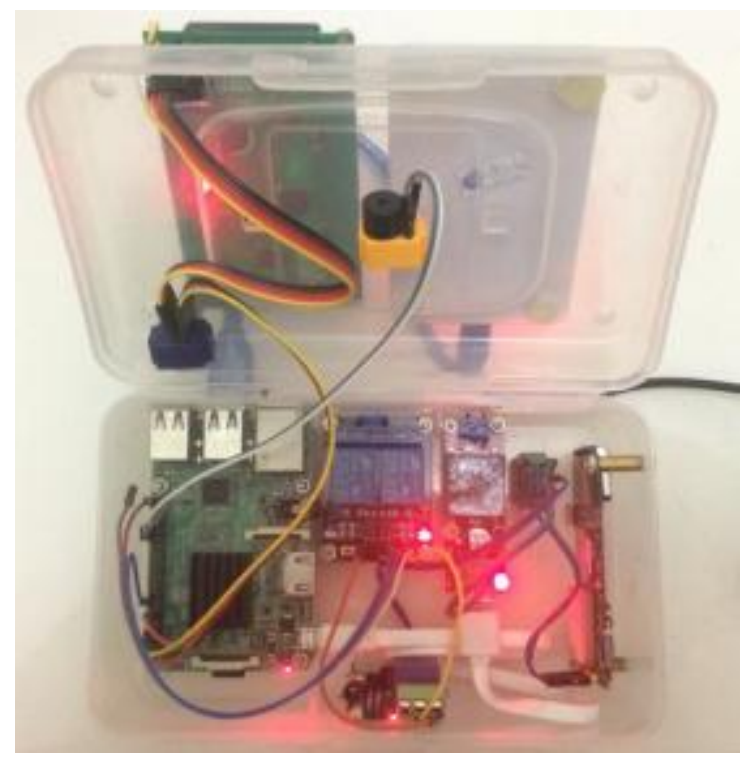

Gambar 5 Sistem tampak dalam.

\subsubsection{Flow Chart Sistem}


RESISTOR (elektRonika kEndali telekomunikaSI tenaga liSTrik kOmputeR) Vol. 2 No. 1 e-ISSN : 2621-9700, p-ISSN : 2654-2684

transmitter berada diluar jangkauan receiver, maka relay 2 akan OFF dan motor akan mati.

3. GPS tracker

Modul GPS ini akan berfungsi lebih baik apabila menghadap langit yang cerah. Apabila RFID sensor dan RF modul berhasil dibobol pencuri dan membawa kabur sepeda motor, maka tingkat pengamanan terakhir yaitu dengan memonitor lokasi keberadaan motor tersebut. Setelah power supply (12 Volt) dihubungkan, kita dapat meminta lokasi modul tersebut berada dengan mengirim pesan "smslink123456" dan mengirim via sms ke nomor SIM card tadi.

\section{PENGUJIAN DAN HASIL}

\subsection{Pengujian RFID}

Pengujian RFID dilakukan untuk mengetahui tingkat keberhasilan pembacaan transponder oleh RFID reader. Tingkat keberhasilan ini diukur dari seberapa jauh jarak antara transponder dengan reader dan seberapa besar sudut antara transponder dan reader yang masih mampu dideteksi (dibaca) tanpa ada kesalahan.

Tabel 1 Hasil pengujian jarak RFID.

\begin{tabular}{|c|c|l|l|l|}
\hline No & Jarak (cm) & Respon RFID Reader & GPIO 21 & Status Relay 1 \\
\hline 1 & 0 & Mendeteksi & High & On \\
\hline 2 & 0.5 & Mendeteksi & High & On \\
\hline 3 & 1 & Mendeteksi & High & On \\
\hline 4 & 1.5 & Mendeteksi & High & On \\
\hline 5 & 2 & Mendeteksi & High & On \\
\hline 6 & 2.5 & Mendeteksi & High & On \\
\hline 7 & 3 & Mendeteksi & High & On \\
\hline 8 & 3.5 & Mendeteksi & High & On \\
\hline 9 & 4 & Mendeteksi & High & On \\
\hline 10 & 4.5 & Tidak mendeteksi & Low & Off \\
\hline 11 & 5 & Tidak mendeteksi & Low & Off \\
\hline 12 & 5.5 & Tidak mendeteksi & Low & Off \\
\hline 13 & 6 & Tidak mendeteksi & Low & Off \\
\hline
\end{tabular}

Dari tabel 1 dapat kita simpulkan bahwa USB RFID reader keluaran SYC Reader ini mampu mendeteksi transponder dengan baik pada jarak $0-$ $4 \mathrm{~cm}$. Sedangkan pada jarak $>4 \mathrm{~cm}$, transponder tidak lagi terdeteksi.

Tabel 2 Hasil pengujian sudut RFID.

\begin{tabular}{|l|c|l|l|l|}
\hline No & Sudut & Respon RFID Reader & GPIO 21 & Status Relay l \\
\hline 1 & $0^{\circ}$ & Mendeteksi & High & On \\
\hline 2 & $10^{\circ}$ & Mendeteksi & High & On \\
\hline 3 & $20^{\circ}$ & Mendeteksi & High & On \\
\hline 4 & $30^{\circ}$ & Mendeteksi & High & On \\
\hline 5 & $40^{\circ}$ & Mendeteksi & High & On \\
\hline 6 & $50^{\circ}$ & Mendeteksi & High & On \\
\hline 7 & $60^{\circ}$ & Mendeteksi & High & On \\
\hline 8 & $70^{\circ}$ & Tidak mendeteksi & Low & Off \\
\hline 9 & $80^{\circ}$ & Tidak mendeteksi & Low & Off \\
\hline 10 & $90^{\circ}$ & Tidak mendeteksi & Low & Off \\
\hline 11 & $100^{\circ}$ & Tidak mendeteksi & Low & Off \\
\hline 12 & $110^{\circ}$ & Tidak mendeteksi & Low & Off \\
\hline 13 & $120^{\circ}$ & Mendeteksi & High & On \\
\hline 14 & $130^{\circ}$ & Mendeteksi & High & On \\
\hline 15 & $140^{\circ}$ & Mendeteksi & High & On \\
\hline 16 & $150^{\circ}$ & Mendeteksi & High & On \\
\hline 17 & $160^{\circ}$ & Mendeteksi & High & On \\
\hline 18 & $170^{\circ}$ & Mendeteksi & High & On \\
\hline 19 & $180^{\circ}$ & Mendeteksi & High & On \\
\hline
\end{tabular}

Dari tabel 2 dapat kita analisa bahwa USB RFID reader keluaran SYC Reader ini mampu mendeteksi transponder dengan baik pada sudut $0^{\circ}$ $60^{\circ}$ dan $120^{\circ}-180^{\circ}$. Sedangkan pada sudut $70^{\circ}-110^{\circ}$ transponder tidak dapat terdeteksi.

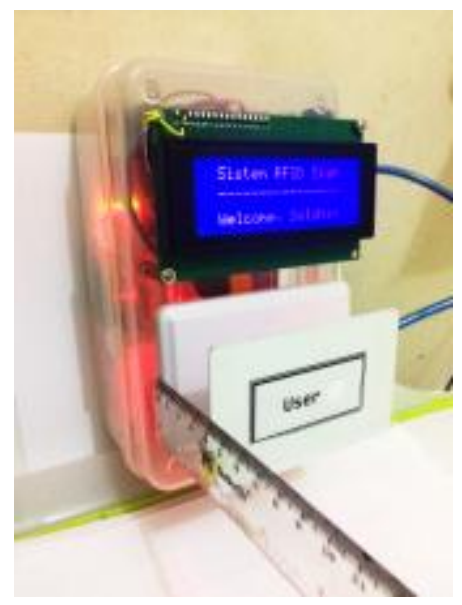

Gambar 7 Pengujian jarak RFID. 
RESISTOR (elektRonika kEndali telekomunikaSI tenaga liSTrik kOmputeR) Vol. 2 No. 1 e-ISSN : 2621-9700, p-ISSN : 2654-2684

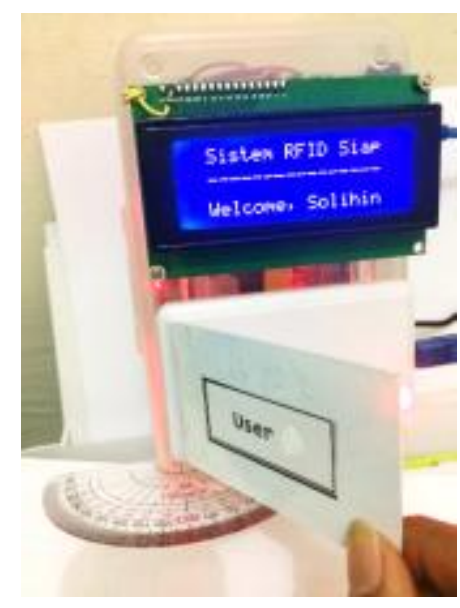

Gambar 8 Pengujian sudut RFID.

\subsection{Pengujian RF Modul}

Pengujian RF modul dilakukan untuk mengetahui berapa jarak maksimal yang dapat dijangkau oleh Tx modul untuk mengirimkan sinyal ke Rx modul. Hal ini bertujuan untuk mengetahui pada jarak berapa sepeda motor akan mati secara otomatis apabila motor dan pengguna terpisah. Pengujian dilakukan pada dua kondisi, yaitu di jalan raya (tanpa penghalang) dan di dalam bangunan dengan ada penghalang berupa tembok solid dengan ada lubang ventilasi di bagian atas.

Tabel 3 Hasil pengujian RF modul tanpa penghalang.

\begin{tabular}{|c|c|l|l|l|}
\hline No & Jarak (m) & \multicolumn{1}{|c|}{ Status Rx Modul } & $\begin{array}{c}\text { Output } \\
\text { Rx modul }\end{array}$ & Status Relay 2 \\
\hline 1 & 1 & Mendeteksi & High & On \\
\hline 2 & 3 & Mendeteksi & High & On \\
\hline 3 & 5 & Mendeteksi & High & On \\
\hline 4 & 9 & Mendeteksi & High & On \\
\hline 5 & 13 & Mendeteksi & High & On \\
\hline 6 & 17 & Mendeteksi & High & On \\
\hline 7 & 20 & Mendeteksi & High & On \\
\hline 8 & 23 & Tidak mendeteksi & Low & Off \\
\hline 9 & 25 & Tidak mendeteksi & Low & Off \\
\hline
\end{tabular}

Berdasarkan tabel 3 di atas, dapat disimpulkan bahwa RF modul dapat berkomunikasi dengan baik pada jarak 0 - 20 meter. Jika modul Tx dan Rx terpisah pada jarak $>20$ meter, maka kedua modul tersebut tidak dapat berkomunikasi sehingga $\mathrm{Rx}$ modul mengeluarkan logika LOW yang menyebabkan Relay 2 menjadi OFF dan mesin sepeda motor pun mati.

Tabel 4 Hasil pengujian RF modul dengan penghalang tembok solid.

\begin{tabular}{|c|c|l|l|l|}
\hline No & Jarak (m) & \multicolumn{1}{|c|}{ Status Rx Modul } & $\begin{array}{c}\text { Output } \\
\text { Rx modul }\end{array}$ & Status Relay 2 \\
\hline 1 & 0,5 & Mendeteksi & High & On \\
\hline 2 & 1 & Mendeteksi & High & On \\
\hline 3 & 1,5 & Tidak mendeteksi & Low & Off \\
\hline 4 & 2 & Tidak mendeteksi & Low & Off \\
\hline 5 & 2,5 & Tidak mendeteksi & Low & Off \\
\hline 6 & 3 & Tidak mendeteksi & Low & Off \\
\hline 7 & 3,5 & Tidak mendeteksi & Low & Off \\
\hline 8 & 4 & Tidak mendeteksi & Low & Off \\
\hline 9 & 4,5 & Tidak mendeteksi & Low & Off \\
\hline 10 & 5 & Tidak mendeteksi & Low & Off \\
\hline
\end{tabular}

Berdasarkan tabel 4 di atas, dapat kita simpulkan bahwa dengan adanya penghalang berupa tembok solid dengan ventilasi di bagian atasnya, maka RF modul sapat berkomunikasi dengan baik pada jarak $0-1$ meter.

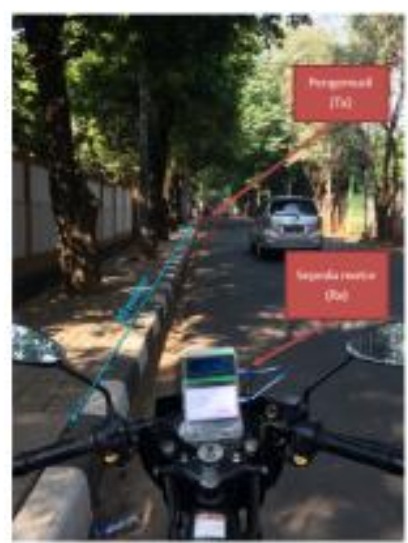

Gambar 9 Pengujian RF modul.

\subsection{Pengujian GPS}

Pengujian GPS dilakukan untuk mengetahui respon waktu yang dibutuhkan oleh perangkat untuk mengirim koordinat lokasi. Selain itu, pengujian juga dilakukan untuk mengetahui tingkat akurasi koordinat lokasi yang dikirim oleh GPS modul melalui SMS. GPS Tracking merupakan teknologi untuk mengetahui posisi dan history posisi suatu obyek secara real time [9].

- Pengujian respon waktu 
RESISTOR (elektRonika kEndali telekomunikaSI tenaga liSTrik kOmputeR) Vol. 2 No. 1 e-ISSN : 2621-9700, p-ISSN : 2654-2684

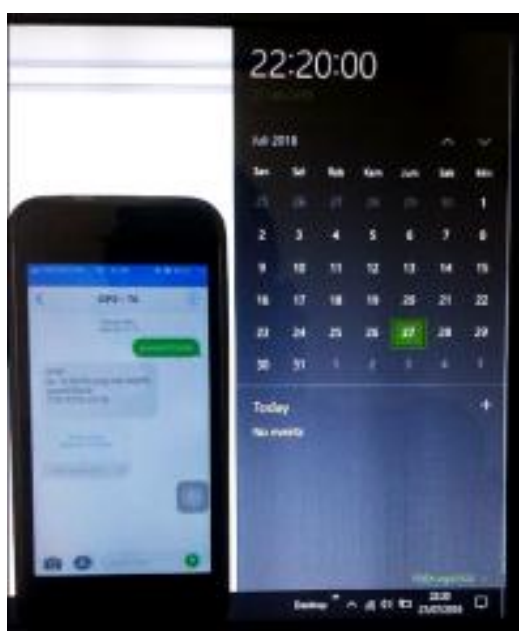

Gambar 10 Pengujian respon waktu GPS.

Tabel 5 Hasil pengujian respon waktu GPS.

\begin{tabular}{|c|c|c|c|}
\hline $\begin{array}{c}\text { Percobaan } \\
\text { ke- }\end{array}$ & $\begin{array}{c}\text { Waktu mengirim } \\
\text { SMS }\end{array}$ & $\begin{array}{c}\text { Waktu menerima } \\
\text { SMS }\end{array}$ & $\begin{array}{c}\text { Lama waktu } \\
\text { respon }\end{array}$ \\
\hline 1 & $22: 19: 34$ & $22: 20: 00$ & 26 detik \\
\hline 2 & $22: 41: 00$ & $22: 41: 28$ & 28 detik \\
\hline 3 & $22: 42: 25$ & $22: 42: 50$ & 25 detik \\
\hline 4 & $23: 01: 20$ & $23: 01: 50$ & 30 detik \\
\hline 5 & $23: 10: 17$ & $23: 10: 43$ & 26 detik \\
\hline
\end{tabular}

Dari tabel 5 di atas dapat dianalisa bahwa rata - rata waktu yang dibutuhkan untuk merespon (mereply) sms dari pengguna adalah:

$$
\begin{aligned}
\overline{\mathbf{X}} & =\frac{26+28+25+30+26}{5}=\frac{135}{5} \\
& =\mathbf{2 7} \text { detik }
\end{aligned}
$$

- Pengujian akurasi GPS

Pengujian akurasi GPS dilakukan dengan cara membandingkan lokasi yang ditunjukkan oleh my location pada aplikasi google map di HP dengan lokasi yang tertera pada SMS balasan dari GPS modul. Jarak antara kedua titik tersebut juga bisa diukur dengan memanfaatkan fitur "ukur jarak" pada aplikasi google map sehingga bisa diketahui berapa meter tingkat kesalahannya. Langkah-langkahnya adalah sebagai berikut:

1. Klik link google map yang ada pada SMS balasan dari GPS modul.

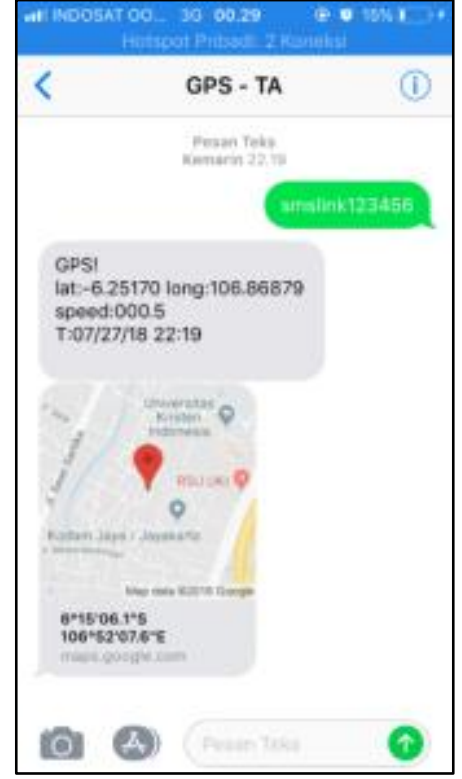

Gambar 11 SMS dari GPS modul.

2. Setelah di klik, secara oto-matis akan beralih ke aplikasi google map. Bulatan berwar-na biru adalah my location, sedangkan pin berwarna merah adalah lokasi yang ditunjukkan oleh GPS modul.

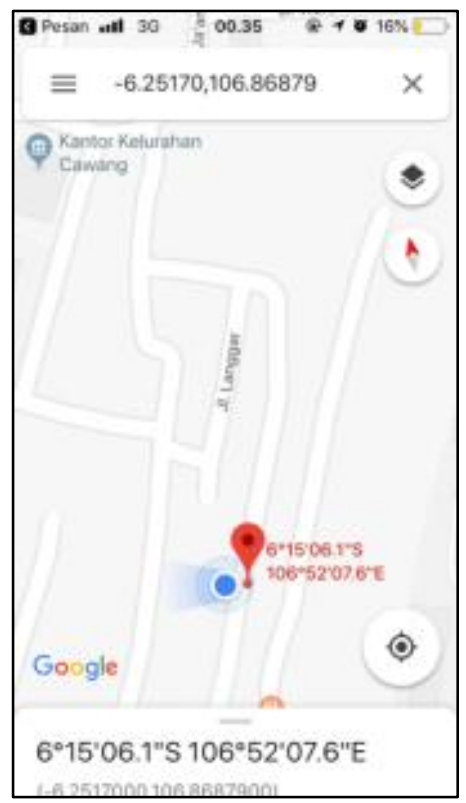

Gambar 12 aplikasi google map.

3. Ukur jarak seperti gambar 13 di bawah. 
RESISTOR (elektRonika kEndali telekomunikaSI tenaga liSTrik kOmputeR) Vol. 2 No. 1 e-ISSN : 2621-9700, p-ISSN : 2654-2684

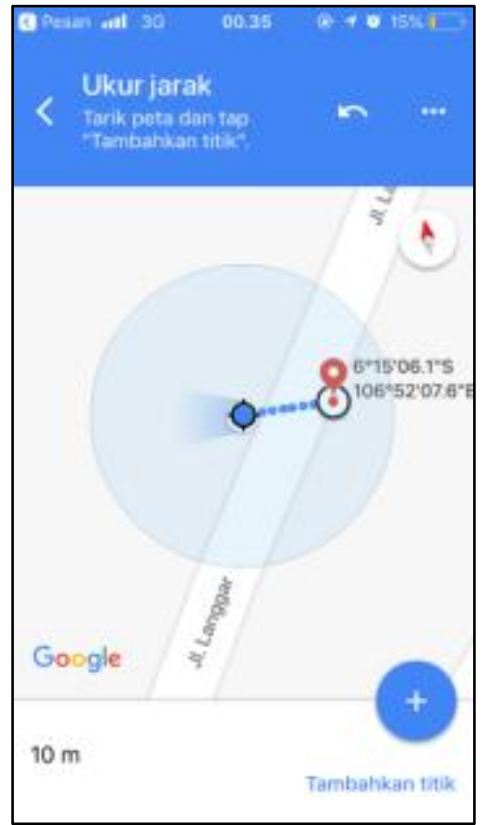

Gambar 13 Ukur jarak di google map

Dari gambar 13 di atas kita bisa mengetahui bahwa selisih antara jarak yang ditunjukkan oleh modul GPS dengan my location pada google maps adalah 10 meter seperti tertera di pojok kiri bawah pada gambar di atas.

- Pengujian Konsumsi Daya

Pengujian ini bertujuan untuk mengetahui berapa arus dan daya yang dikonsumsi / diserap oleh sistem (alat) yang dibuat, dan juga untuk mengetahui lama waktu pemakaian aki.

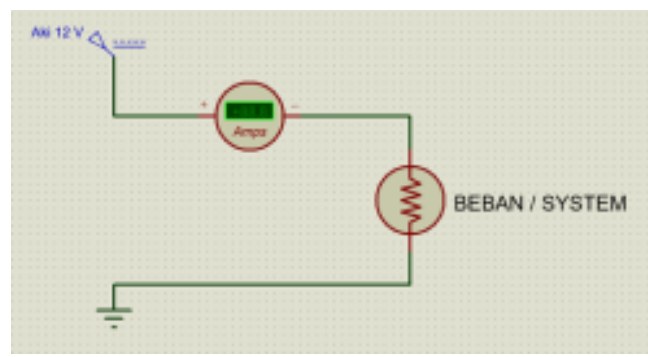

Gambar 14 Skema pengukuran arus.

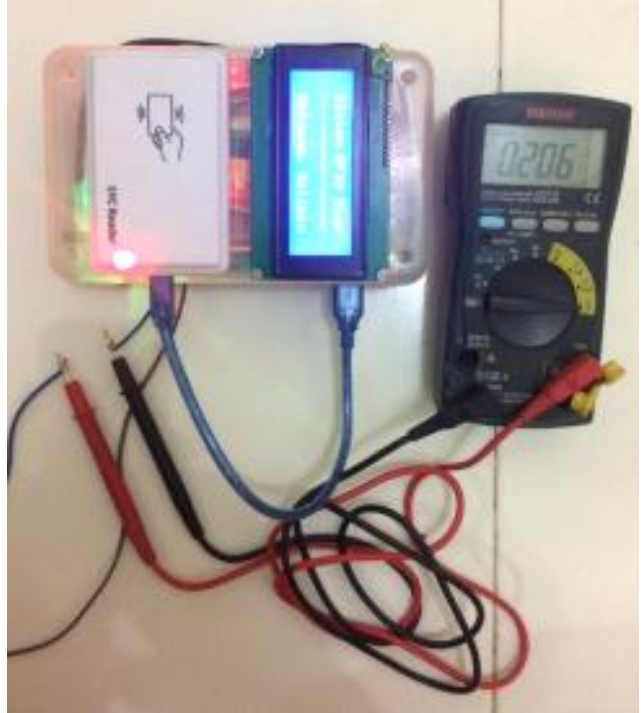

Gambar 15 Hasil pengukuran arus.

Berdasarkan hasil pengukuran meng-gunakan multimeter yang ditunjukkan pada gambar 15 di atas, arus yang dikonsumsi oleh perangkat adalah sebesar 0,206 Ampere. Dengan menggunakan hukum Ohm diperoleh:

Daya yang diserap system $=\mathrm{P}$

$\mathrm{P}=\mathrm{V}$. I

$\mathrm{P}=12 \mathrm{~V} \cdot 0,206 \mathrm{~A}$

$\mathrm{P}=2,472$ Watt

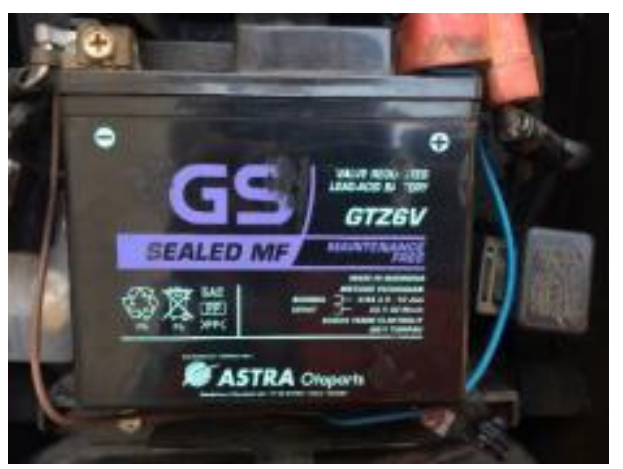

Gambar 16 Aki motor satria FU.

Apabila aki berada dalam kondisi full, dengan melihat spesifikasi aki yang digunakan adalah $6 \mathrm{AH}$, maka perhitungan lama waktu pemakaian adalah sebagai berikut:

Lama waktu $=t$

$t=$
$\left(\frac{\text { Kapasitas aki }}{\text { Arus pemakaian }}\right)-$ disipasi daya aki $20 \%$ 
RESISTOR (elektRonika kEndali telekomunikaSI tenaga liSTrik kOmputeR) Vol. 2 No. 1 e-ISSN : 2621-9700, p-ISSN : 2654-2684

$$
\begin{aligned}
t & =\left(\frac{6 A H}{0,206 A}\right)-\text { disipasi daya aki } 20 \% \\
t & =29,13 H-\text { disipasi daya aki } 20 \% \\
t & =29,13 H-5,826 \mathrm{H} \\
t & =23,304 \mathrm{H}(23 \mathrm{Jam} 18 \text { menit } 14,4 \text { detik })
\end{aligned}
$$

\section{KESIMPULAN}

Berdasarkan hasil pengujian yang telah dilakukan, maka dapat disimpulkan beberapa hal sebagai berikut:

1. Pada pengujian RFID, jarak maksimal yang dapat dide-teksi antara transponder de-ngan reader adalah $4 \mathrm{~cm}$. Sedangkan untuk sudut antara transponder dengan reader yang dapat di deteksi adalah $0^{\circ}-60^{\circ}$ dan $120^{\circ}-180^{\circ}$.

2. Pada pengujian GPS modul, rata - rata waktu yang dibutuhkan oleh GPS modul untuk mengirimkan sms balasan yang berisi data lokasi adalah 27 detik dihitung sejak SMS dikirim oleh pengguna.

3. Pada pengujian akurasi GPS modul, tingkat kesalahan yang terjadi adalah 10 meter yang diukur menggunakan fitur "ukur jarak" antara my location sampai dengan titik yang ditunjuk oleh GPS modul pada aplikasi google map.

4. Pada pengujian RF modul, jarak maksimal untuk berkomunikasi antara Tx dan Rx modul adalah 20 meter apabila diuji tanpa ada penghalang. Sedangkan pengukuran RF modul dengan penghalang berupa tembok solid dengan ada ventilasi di bagian atas, jarak maksimalnya adalah 1 meter.

\section{UCAPAN TERIMA KASIH}

Terima kasih diucapkan kepada Fakultas Teknik Universitas Muhammadiyah Jakarta yang telah mendanai penelitian ini melalui hibah PAKARTI dengan kontrak nomor 191 A /FT$\mathrm{UMJ} / \mathrm{XII} / 2018$

\section{DAFTAR PUSTAKA}

[1] H. Isyanto and M. Syahrullah, "Perancangan Security Home (Keamanan pada Rumah) Menggunakan Mikrokontroller Berbasis SMS (Short Message Service)," vol. 1, no. 2, p. 12.

[2] N. Rohman, F. Setyawan, A. A. Fikri, A. nur Fuad, R. Rohim, and R. Firmansyah, "Telemetri Flowmeter Menggunakan RF Modul 433MHz," Journal of Electrical and Electronics Engineering UMSIDA, vol. 1, no. 1, pp. 8-14, 2017.

[3] H. H. RACHMAT and G. A. HUTABARAT, "Pemanfaatan Sistem RFID sebagai Pembatas
Akses Ruangan," ELKOMIKA: Jurnal Teknik Energi Elektrik, Teknik Telekomunikasi, \& Teknik Elektronika, vol. 2, no. 1, p. 27, 2014.

[4] M. R. Alwin, A. Suyatno, and I. F. Astuti, "Implementasi RFID Tag Pasif Sebagai Pengaman Tambahan Pada Sepeda Motor," Informatika Mulawarman: Jurnal Ilmiah Ilmu Komputer, vol. 7, no. 2, pp. 55-57, 2016.

[5] S. T. Akhmad Zainuri, "Implementasi Rfid Sebagai Pengaman Pada Sepeda Motor Untuk Mengurangi Tindak Pencurian," Jurnal Mahasiswa TEUB, vol. 2, no. 7, 2015.

[6] E. Rakhman, F. Candrasyah, and F. D. Sutera, "Raspberry Pi: Mikrokontroler Mungil Yang Serba Bisa," Yogyakarta: Penerbit Andi, 2014.

[7] H. Muchtar and R. Sumanjaya, "Control Switch Otomatis pada Tegangan Energi Alternatif dan Tegangan Sumber PLN Menggunakan Raspberry Pi," RESISTOR (elektRonika kEndali telekomunikaSI tenaga liSTrik kOmputeR), vol. 1, no. 2, 2018.

[8] D. C. Putri, "PENGAPLIKASIAN SENSOR RFID SEBAGAI KUNCI KONTAK OTOMATIS PADA KENDARAAN BERMOTOR RODA DUA BERBASIS ARDUINO UNO," PhD Thesis, Politeknik Negeri Padang, 2016.

[9] I. Novrizal, "Perancangan Sistem APRS (Automatic Positioning/Packet Reporting System) Untuk Mendapatkan Data Posisi Realtime Tim Rescue Yang Dibutuhkan Dalam Pengendalian Search And Rescue (SAR) Dengan Munggunakan Raspberry Pi3 [Unpublished]," Universitas Muhammadiyah Jakarta, 2018. 
RESISTOR (elektRonika kEndali telekomunikaSI tenaga liSTrik kOmputeR) Vol. 2 No. 1 e-ISSN : 2621-9700, p-ISSN : 2654-2684 